\title{
CHARACTERIZATION OF NiO NANOPARTICLES PREPARED USING GELATIN AND A LOW-COST SYNTHESIS
}

\author{
Violeta N. Nikolića , Martina D. Gilić ${ }^{b}$, Vojislav V. Spasojevićc \\ a University of Belgrade, Vinča Institute of Nuclear Sciences, \\ Department of Theoretical Physics and Condensed Matter Physics, \\ Belgrade, Republic of Serbia, \\ e-mail: violeta@vin.bg.ac.rs, \\ ORCID iD: (iohttps://orcid.org/0000-0002-5685-3219 \\ ${ }^{\mathrm{b}}$ University of Belgrade, Institute of Physics, Department of research in \\ the field of electronic materials, Belgrade, Republic of Serbia, \\ e-mail: martina@ipb.ac.rs, \\ ORCID iD: (1)https://orcid.org/0000-0002-5715-7717 \\ c University of Belgrade, Vinča Institute of Nuclear Sciences, \\ Department of Theoretical Physics and Condensed Matter Physics, \\ Belgrade, Republic of Serbia, \\ e-mail: vojas@vin.bg.ac.rs, \\ ORCID iD: (1) http://orcid.org/0000-0002-6134-8989
}

DOI: 10.5937/vojtehg67-18535; https://doi.org/10.5937/vojtehg67-18535

\begin{abstract}
FIELD: Chemical Technology
ARTICLE TYPE: Original Scientific Paper

ARTICLE LANGUAGE: English
\end{abstract}

\begin{abstract}
Summary:
Nanocomposite material containing $\mathrm{NiO}$ nanoparticles decorated on $\mathrm{WO}_{3}$ nanowires could be used for monitoring levels of $\mathrm{H}_{2} \mathrm{~S}$ gas. The effectiveness of this material is mostly determined by NiO properties. The performed study presents the first stage in the preparation of modified $\mathrm{NiO} \mathrm{WO}_{3}$ nanocomposite material. In this article, NiO nanoparticles are prepared by a simple, low-cost method. The behavior of nano-sized NiO particles is probed by X-ray diffraction, Fourier transform Infrared Spectroscopy, Raman spectroscopy, and hysteretic measurement.
\end{abstract}

Key words: NiO, diffraction measurements, spectroscopy, nanoparticles, materials.

ACKNOWLEDGMENT: This work has been supported by the Ministry of Education, Science and Technological Development of the Republic of Serbia (2011-2018), under Grant No. III 45015. 


\section{Introduction}

Transition metal ( $\mathrm{Fe}, \mathrm{Co}, \mathrm{Ni}$ and $\mathrm{Mn}$ ) oxide nanoparticles have been thoroughly examined in recent years due to discoveries of new applications of these materials (Sellmyer et al, 2001), (Jana et al, 2004), (Nikolić et al, 2016), (Nikolić et al, 2017), which is enabled by their modified properties that are significantly improved in comparison to bulk materials. Today, $\mathrm{NiO}$ nanoparticles are intensively investigated because of their various potential applications in different industries.

Nickel oxide materials are recognized as interesting for usage in catalytic reactions in industrial processes and electrochromic devices (Salimi et al, 2017), (You et al, 2003), (Xing et al, 2004), (Kamal et al, 2005), (Lee et al, 2014). One of potential applications of $\mathrm{NiO}$ nanoparticles in this field presents the fabrication of a glucose biosensor based on the electrochemical co-deposition of $\mathrm{NiO}$ and $\mathrm{GOx}$ (glucose oxidase) onto the surface of the GC (glucose consumption) electrode (Salimi et al, 2017). Further, the investigation of the influence of the $\mathrm{NiO}$ properties on the electrochemical properties of $\mathrm{NiO} /$ reduced graphene oxide-based supercapacitor electrodes is of importance for designing high performance energy storage devices constructed from materials with limited conductivity (Lee et al, 2014).

It is noteworthy that the examination of the properties of composite materials containing $\mathrm{NiO}$ nanoparticles could contribute to the development of inexpensive resistive sensors able to monitor the presence of $\mathrm{H}_{2} \mathrm{~S}$ in the environment, which is of significance for military industry. Jeffrey pointed to many potential hazards for workers involved in operation and maintenance of water and wastewater treatment systems (Jeffrey, 2015). Workers in navy air forces are often faced with the problem of the presence of explosive gases (such as methane $\left(\mathrm{CH}_{4}\right)$, carbon monoxide $(\mathrm{CO})$ and hydrogen sulfide $\left(\mathrm{H}_{2} \mathrm{~S}\right)$ ). In combination with the air and a spar, the mentioned gases are prone to strong explosions that could lead to significant damage in confined spaces (tanks, underground lift stations, manholes) (Jeffrey, 2015). Also, it is important to notice that in wastewater treatment systems, $\mathrm{H}_{2} \mathrm{~S}$ gas is present more often than any other hazardous gas (Jeffrey, 2015). After longer exposure, workers experience over-stimulation of all sensors and are not capable of registering $\mathrm{H}_{2} \mathrm{~S}$ odor. With the aim to overcome the mentioned problem, scientific community have performed more detailed research in $\mathrm{H}_{2} \mathrm{~S}$ sensors properties; literature data show that the behavior of $\mathrm{H}_{2} \mathrm{~S}$ sensors varies depending on the properties of material used for their construction (Rout et al, 2008), (Lin et al, 1994), (Wang et al, 2008), 
(Kapse et al, 2008), (MalekAlaie et al, 2015). Navarrete et al. found that tungsten oxide $\left(\mathrm{WO}_{3}\right)$ nanowires decorated with $\mathrm{NiO}$ nanoparticles could be applied onto substrates for developing resistive metal oxide gas sensors (Navarrete et al, 2018). These nanocomposite materials showed increased sensitivity and selectivity to $\mathrm{H}_{2} \mathrm{~S}$, and achieved a five-fold increase in the response, which is ascribed to the $\mathrm{NiO}$ high chemical adsorption effect as well as to the high electronic sensitization effect (NiO nanoparticles become metallic $\mathrm{Ni}_{x} \mathrm{~S}_{x}$ upon exposure to $\mathrm{H}_{2} \mathrm{~S}$ ).

The well-known gas sensing properties of the material consisting of nickel oxide (NiO) nanoparticles decorating tungsten oxide $\left(\mathrm{WO}_{3}\right)$ nanowires are significantly dependent on the properties of both present phases: $\mathrm{NiO}$ and $\mathrm{WO}_{3}$ nanostructures. Although Navarrete et al obtained the mentioned material by performing a two-step synthesis (the first step presented the formation of pure tungsten oxide nanowires, and the second step considered loading these wires with $2 \mathrm{~nm}$-sized $\mathrm{NiO}$ nanoparticles) (Navarrete et al, 2018), experience with other nanomaterials has revealed that the same material could be characterized by different properties if it is obtained by the modified synthesis procedure (Milić et al, 2017). Navarrete started the synthesis from expensive nickel(II)acetylacetonate (Navarrete et al, 2018) that is not appropriate for industry usage since industry always looks for lowcost solutions. One of potential synthesis approaches for the production of $\mathrm{NiO} / \mathrm{WO}_{3}$ nanocomposite material is to change the synthesis route performed for the preparation of $\mathrm{NiO}$ nanoparticles in order to estimate the best candidate for the discussed purpose.

Also, the literature review has revealed that it is not clear how variations in the size of $\mathrm{NiO}$ nanoparticles influence their chemical and electronic sensitization properties to $\mathrm{H}_{2} \mathrm{~S}$. In Ref. (Navarrete et al, 2018), it is shown that the increased sensitivity and selectivity to $\mathrm{H}_{2} \mathrm{~S}$ is achieved by using $2 \mathrm{~nm} \mathrm{NiO}$ nanoparticles. Having in mind that nanoparticles lower in size than $10 \mathrm{~nm}$ show different behavior compared to the nanoparticles of the same chemical composition but bigger in size (which is a consequence of more pronounced surface effects (Alkilany et al, 2009), (Cheng et al, 2006), (Kossyrev et al, 2005), (Müller et al, 2005), (Tramsdorf et al, 2007), it is difficult to predict whether $\mathrm{NiO}$ nanoparticles bigger than $10 \mathrm{~nm}$ will experience higher or lower sensitivity to $\mathrm{H}_{2} \mathrm{~S}$ gas detection, and this still has not been investigated in literature.

In order to investigate suitability of bigger $\mathrm{NiO}$ nanoparticles $(\sim 40$ $n m$ ) for the detection of $\mathrm{H}_{2} \mathrm{~S}$, this article presents the synthesis of $\mathrm{NiO}$ nanoparticles by a simple and low-cost coprecipitation method. This investigation is the first stage in the preparation of $\mathrm{NiO} / \mathrm{WO}_{3}$ 
nanocomposite material whose sensitivity and selectivity for $\mathrm{H}_{2} \mathrm{~S}$ will be investigated further in the future.

The characterization of the prepared $\mathrm{NiO}$ phase was performed by several techniques. X-ray diffraction (XRD) measurements were done by a Rigaku RINT-TTRIII using CuKa $(\lambda=1.5418 \mathrm{~A})$. Diffraction patterns were recorded in the $2 \theta$ range $\left(10-70^{\circ}\right)$ with a scanning rate of 0.02 $\% / \mathrm{min}$. The Qualx Program was used for data analysis. Pure $\mathrm{NiO}$ nanoparticles were further investigated by Fourier transform infrared spectroscopy (Nicolet IS 50 FTIR Spectrometer, using the attenuated total reflectance (ATR) sampling technique). Raman spectroscopy was performed by micro Raman and the results analyzed using a Jobin-Yvon T64000 spectrometer equipped with a nitrogen cooled charge-coupled device detector. The measurement was done at $20 \mathrm{~mW}$, using $532 \mathrm{~nm}$ green line as the excitation source, and the spectrum was recorded in back scattering geometry. Hysteretic measurement of the sample was carried out using a Quantum Design superconducting quantum interference device (SQUID). Hysteresis was recorded in a temperature range of $2-300 \mathrm{~K}$ for the applied magnetic fields from -50 to $+50 \mathrm{kOe}$.

\section{Experimental results and discussion}

\section{Synthesis of the samples}

Two samples were prepared by a combination of the coprecipitation method and the annealing treatment (Maia et al, 2006). $6.365 \mathrm{~g}$ of nickel (II) chloride $\left(\mathrm{NiCl}_{2} \cdot 6 \mathrm{H}_{2} \mathrm{O}\right)$ and $15.913 \mathrm{~g}$ of commercial colorless gelatin were dissolved in $636 \mathrm{ml}$ of distilled $\mathrm{H}_{2} \mathrm{O}$. The solution was magnetically stirred for 10 minutes at $40{ }^{\circ} \mathrm{C}$ and subsequently kept at $80{ }^{\circ} \mathrm{C}$ for several days. The obtained gel was annealed at $700{ }^{\circ} \mathrm{C}$ for 30 minutes. When the annealing process was completed, green powder was rinsed several times with distilled water. Finally, the excess of water was evaporated.

Another sample was obtained in the same way, with the only difference that sodium hydroxide $(2.2 \mathrm{~g}$ of $\mathrm{NaOH}$ dissolved in a small amount of water) was poured into the stirring solution. The sample was further subjected to the identical procedure. After the annealing treatment, the obtained powder was green and its surface was covered by a thin layer of white powder. The washing process was repeated 4 times.

\section{$X$-ray diffraction measurements}

The diffraction patterns of the samples obtained with and without using $\mathrm{NaOH}$ are presented in Figure 1 and Figure 2, respectively. 


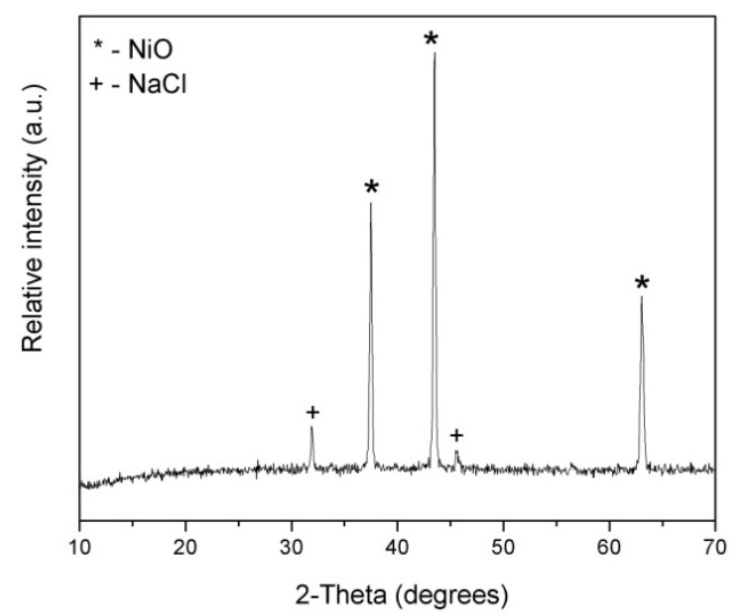

Figure $1-X R D$ pattern of the sample prepared by using $\mathrm{NaOH}$ Puc. 1 - Дифрактограмма образца, подготовленного при использовании $\mathrm{NaOH}$ Слика 1 - Дифрактограм узорка припремљеног коришћењем $\mathrm{NaOH}$

The sample presented in Fig.1 contained two phases, NiO (Qualx card No. 00-101-0093) and sodium chloride, NaCl (Qualx card No. 00100-0041). Scherrer's formula was used to estimate the diameter crystallite size, $d_{c r}$. Both observed phases are nano-sized: $d_{\mathrm{cr}}(\mathrm{NiO}, 2 \theta=$ $\left.43.6^{\circ}\right)=34 \mathrm{~nm}, \mathrm{~d}_{\mathrm{cr}}\left(\mathrm{NaCl}, 2 \theta=31.9^{\circ}\right)=36 \mathrm{~nm}$, although the difference in the quantity and crystallinity of the observed phases resulted in significantly different intensity of the characteristic diffraction maxima.

Literature data proposed a mechanism for the preparation of $\mathrm{NiO}$ nanoparticles by using $\mathrm{NaOH}$ (Bahari Molla Mahaleh et al, 2008):

$$
\begin{aligned}
& 2 \mathrm{NaOH}_{(s)} \rightarrow 2 \mathrm{Na}^{+}{ }_{(a q)}+2 \mathrm{OH}^{-}{ }_{(a q)} \\
& \mathrm{NiCl}_{2} \cdot 6 \mathrm{H}_{2} \mathrm{O}_{(s)} \rightarrow \mathrm{Ni}^{2+}{ }_{(a q)}+2 \mathrm{Cl}^{-}{ }_{(a q)}+6 \mathrm{H}_{2} \mathrm{O}_{(a q)} \\
& \mathrm{Ni}(\mathrm{OH})_{2 x} \cdot\left(\mathrm{H}_{2} \mathrm{O}\right)_{(s)} \rightarrow \mathrm{Ni}(\mathrm{OH})_{2(s)}+{ }_{x} \mathrm{H}_{2} \mathrm{O}_{(g)} \text { (lower temperatures) } \\
& \mathrm{Ni}(\mathrm{OH})_{2(s)} \rightarrow \mathrm{NiO}_{(s)}+\mathrm{H}_{2} \mathrm{O}_{(g)} \text { (higher temperatures). }
\end{aligned}
$$

The absence of the usage of surfactant (polyvinilpyrolidone, polyethylene glycol, or cetyl trimethyl ammonium bromide) during the synthesis procedure resulted in the pronounced reaction:

$$
2 \mathrm{Na}_{(a q)}^{+}+2 \mathrm{Cl}_{(a q)}^{-} \rightarrow 2 \mathrm{NaCl}_{(a q)} .
$$


When the solubility product of $\mathrm{NaCl}$ is overcome, a physical transformation

$\mathrm{NaCl}_{(a q)} \rightarrow \mathrm{NaCl}_{(s)}$ takes place, and $\mathrm{NaCl}$ arises as an impurity. The observed presence of $\mathrm{NaCl}$ pointed to the fact that the sample had been washed with an insufficient amount of water.

Figure 2 presents the sample obtained without $\mathrm{NaOH}$. According to $2 \theta$ positions of the diffraction maxima, the sample contained a pure $\mathrm{NiO}$ phase of high crystallinity, $\mathrm{d}_{\mathrm{cr}}\left(2 \theta=43.6^{\circ}\right)=42 \mathrm{~nm}$. The hkl planes corresponding to the positions of the diffraction maxima are shown in Fig. 2.

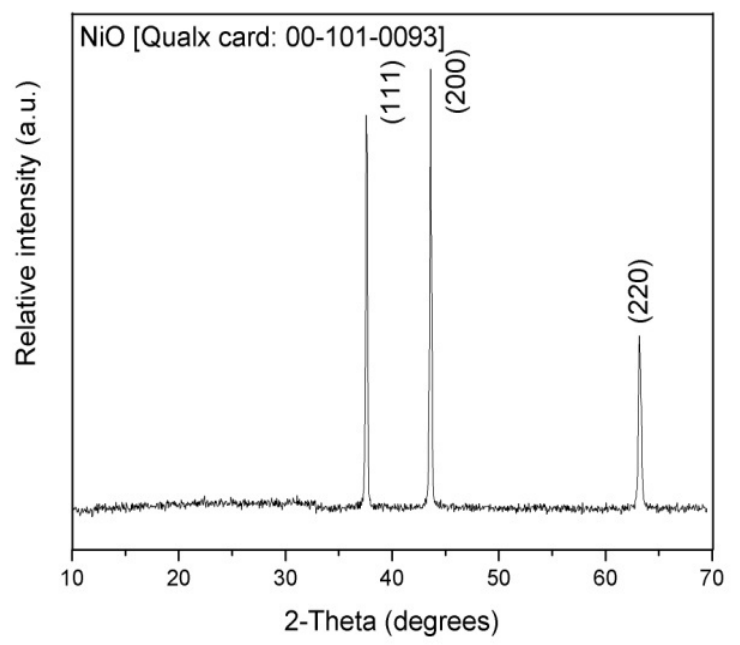

Figure $2-X R D$ pattern of the sample prepared without using $\mathrm{NaOH}$ Puc. 2 - Дифрактограмма образца, подготовленного без $\mathrm{NaOH}$ Слика 2 - Дисррактограм узорка припремљеног без $\mathrm{NaOH}$

If we recall the literature data, it can be noticed that Maia et al. obtained pure $\mathrm{NiO}$ by using $\mathrm{NaOH}$ in the synthesis, but performing annealing at $350{ }^{\circ} \mathrm{C}$ for different annealing times (9-12 hours) (Maia et al, 2006). On the other hand, they reported that the synthesis procedure without $\mathrm{NaOH}$, followed by annealing at $700{ }^{\circ} \mathrm{C}$ for 30 minutes, resulted in the formation of bigger $\mathrm{NiO}$ nanoparticles, $62-78 \mathrm{~nm}$ (nearly two time bigger size than the size of the prepared $\mathrm{NiO}$ particles - Figure 2). The observed discrepancies between the experimental results could be explained in term of the differences in the composition of the used commercial gelatin.

Based on Figures 1 and 2, it can be concluded that the obtained $\mathrm{NiO}$ nanoparticles had a lot of similarities in size and structural properties (the 
diffraction maxima ascribed to the $\mathrm{NiO}$ phase in both samples appeared very similar). For this reason, the investigation of the properties of $\mathrm{NiO}$ nanoparticles continued with the sample containing pure $\mathrm{NiO}$ nanoparticles.

\section{FTIR measurement}

To investigate the surface of the prepared $\mathrm{NiO}$ nanoparticles, the FTIR spectrum was recorded in the mid-wave infrared region, between 2000 and $400 \mathrm{~cm}^{-1}$. Figure 3 presents the spectrum in the range 1300 $400 \mathrm{~cm}^{-1}$, since in the region $1300-2000 \mathrm{~cm}^{-1}$ the curve is presented as a straight line.

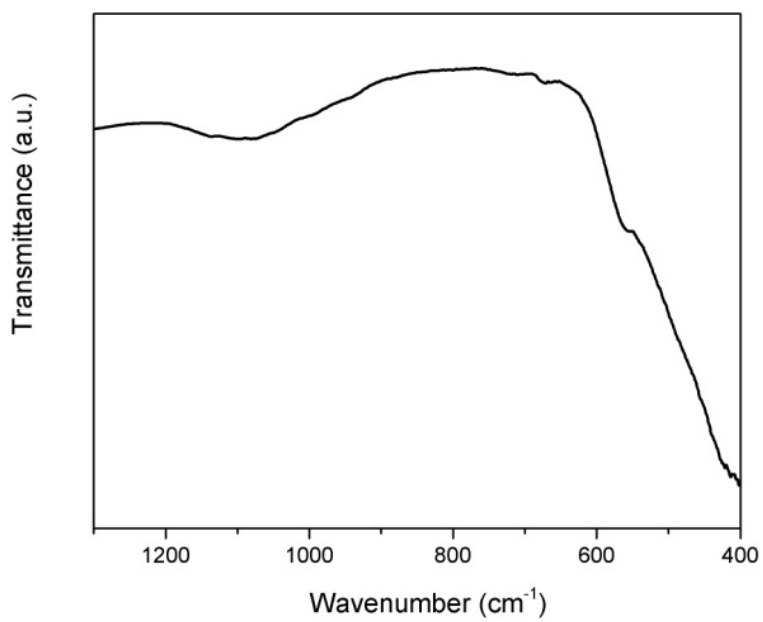

Figure 3 - FTIR spectrum of the sample prepared without using $\mathrm{NaOH}$ Puc. 3 - FTIR спектра образца, подготовленного без $\mathrm{NaOH}$

Слика 3 - FTIR спектар узорка припремљеног без $\mathrm{NaOH}$

In the low-wavenumber part of the spectrum, there is a shoulder noticeable around $530 \mathrm{~cm}^{-1}$ and it can be ascribed to $\mathrm{Ni}$ - O vibration (Rahdar et al, 2015). A small peak at $640 \mathrm{~cm}^{-1}$ could be ascribed to stretching vibrations of the $\mathrm{Ni}-\mathrm{O}-\mathrm{H}$ bond (Rahdar et al, 2015). The observed vibrations confirmed the formation of $\mathrm{NiO}$ nanoparticles although the positions of both vibrations were shifted to higher wavenumber values, which is often a consequence of the presence of moisture in the sample. This is confirmed by the presence of a broad bond around $1080 \mathrm{~cm}^{-1}$. Since one of the precursors in the synthesis was gelatin, and having in mind that $\mathrm{C}-\mathrm{O}$ and $\mathrm{C}-\mathrm{C}$ vibrations appear in the FTIR spectrum in the region $1090-1050 \mathrm{~cm}^{-1}$ (Faust, 1997), the 
observed bond points to the presence of gelatin carbon residues attached to the surface of $\mathrm{NiO}$ nanoparticles. It is important here to notice that the observed gelatin moisture is present after annealing at $700{ }^{\circ} \mathrm{C}$, although Chuaynukul et al found that the degradation of gelatin occurred around $250{ }^{\circ} \mathrm{C}$ (Chuaynukul et al, 2014). This is a neither usual nor surprising result, since literature data reveal a well-known fact that substantial variations in the compositions of many commercial gelatins result in shifting gelatin degradation temperatures (Ling, 1978).

According to Figure 2 and Figure 3 , it can be assumed that the investigated sample contained $\mathrm{NiO}$ nanoparticles, and that carbon residues were attached to the $\mathrm{NiO}$ nanoparticle surface.

\section{Raman measurement}

The Raman spectrum of the investigated sample in the spectral range from 100 to $1200 \mathrm{~cm}^{-1}$ is shown in Figure 4 .

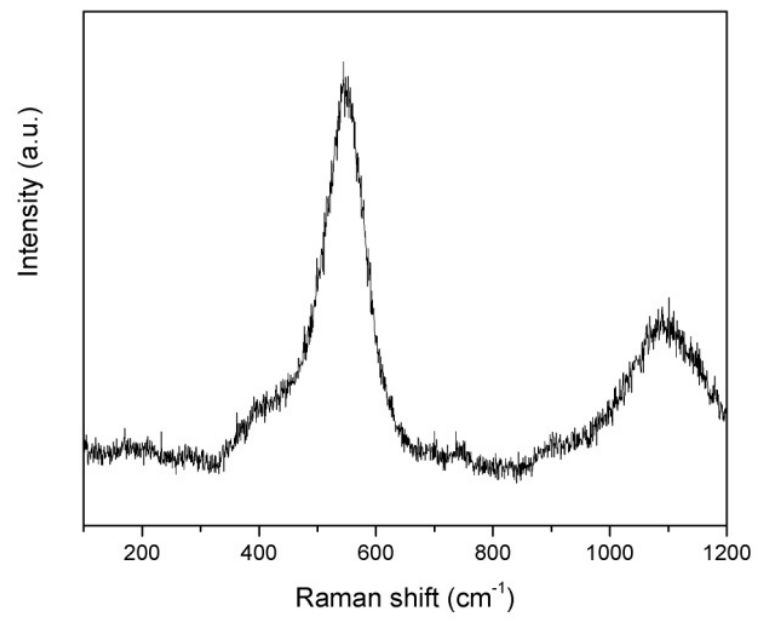

Figure 4 - Raman spectrum of the sample prepared without using $\mathrm{NaOH}$ Puc. 4 - Рамановский спектр образца, подготовленного без $\mathrm{NaOH}$ Слика 4 - Рамански спектар узорка припремљеног без $\mathrm{NaO}$

It can be easily observed that Figure 4 is in accordance with Figure 3. The peak about $530 \mathrm{~cm}^{-1}$ points to the presence of $\mathrm{NiO}$ nanoparticles, and arises due to the Ni-O stretching mode (Cordoba-Torresi et al, 1991). The mode around $1085 \mathrm{~cm}^{-1}$ depicts the appearance of carbon moisture. The results obtained by using Raman spectroscopy confirmed the data observed by FTIR spectroscopy. 
To understand the observed results, it is important to elucidate the mechanism of the formation of $\mathrm{NiO}$ nanoparticles by using gelatin in the synthesis procedure.

In literature, the chemical content of gelatin is often described as a mixture of hydroxyproline $\left(\mathrm{C}_{5} \mathrm{H}_{9} \mathrm{NO}_{3}\right)$, proline $\left(\mathrm{C}_{5} \mathrm{H}_{9} \mathrm{NO}_{2}\right)$ and glycine $\left(\mathrm{C}_{2} \mathrm{H}_{5} \mathrm{NO}_{2}\right)$, in different ratios (Jagadeesh et al, 2016). The sequence that describes gelatin, Gly-X-Y (where Gly refers to glycine, and $X$ and $Y$ are proline and hydroxyproline, respectively (Samouillan et al, 2011)), presents the triple helical structure of three left-handed polyproline type helices twisted into a superhelix. Thermal treatment initiated triple helix unfolds to produce random chains of gelatin (Harrington \& von Hippel, 1969), that could be covalently linked to each other or not, depending on the annealing temperature (Privalov et al, 1979) (Balian \& Bowes, 1977).

The proposed mechanism of the performed synthesis could be described in terms of the reaction between nickel salt and glycine:

$$
\mathrm{NiCl}_{2} \cdot 6 \mathrm{H}_{2} \mathrm{O}_{(s)}+\mathrm{C}_{2} \mathrm{H}_{5} \mathrm{NO}_{2(s)} \rightarrow\left[\mathrm{NiCl}_{2}\left(\mathrm{C}_{2} \mathrm{H}_{5} \mathrm{NO}_{2}\left(\mathrm{H}_{2} \mathrm{O}\right)_{2}\right)\right]_{n(s)}
$$

Fleck \& Bohaty (Fleck \& Bohaty, 2004) pointed out the main characteristic of this compound - containing helical chains of $\left[\mathrm{NiO}_{4} \mathrm{Cl}_{2}\right]$ octahedra connected by glycine molecules. It is noteworthy that literature data reveal that octahedral nickel-chloride complexes are characterized by a low value for the octahedral $\mathrm{Ni}-\mathrm{Cl}$ bond order, which is caused by steric interactions between $\mathrm{Cl}^{-}$and other ligands in the octahedral coordination sphere (See et al, 1998). Accordingly, the annealing process results in the release of chloride ions and their transformation to chloride gas. As a result, $\mathrm{NiO}$ nanoparticles containing surface organic impurities (originated from glycine molecules that connected $\left[\mathrm{NiO}_{4} \mathrm{Cl}_{2}\right]$ units) are obtained.

It is important to notice that gelatin could be obtained from vegatable origin (algae), or from animal origin (fish or bovine). Also, literature data confirmed that different manufacturers sometimes add formaldehyde or glutaraldehyde in the gelatin preparation in order to ensure hardening of gelatin (Chiellini et al, 2001). Since the chemical composition of gelatin varies dependent on the origin of gelatin, as well as on the manufacturing procedure, the purity of $\mathrm{NiO}$ nanoparticles could be improved by varying the synthesis parameters, which could be done by two different approaches: to change the type of gelatin, or to use gelatin manufactured by different producers. 


\section{SQUID measurement}

Although SQUID measurements allowed the investigation of the magnetic properties of the sample, this type of examination is important for the estimation of the suitability of $\mathrm{NiO}$ nanoparticles for gas sensing application due to the coupling between the electric and magnetic fields in the $\mathrm{NiO}$ nanoparticle system. Since $\mathrm{NiO}$ nanoparticles showed different magnetic properties dependent on the type of synthesis and their structural properties, a significant deviation from the desired magnetic properties could be ascribed to the alteration of $\mathrm{NiO}$ electronic properties.

The hysteretic loops of the sample are shown in Figure 5.

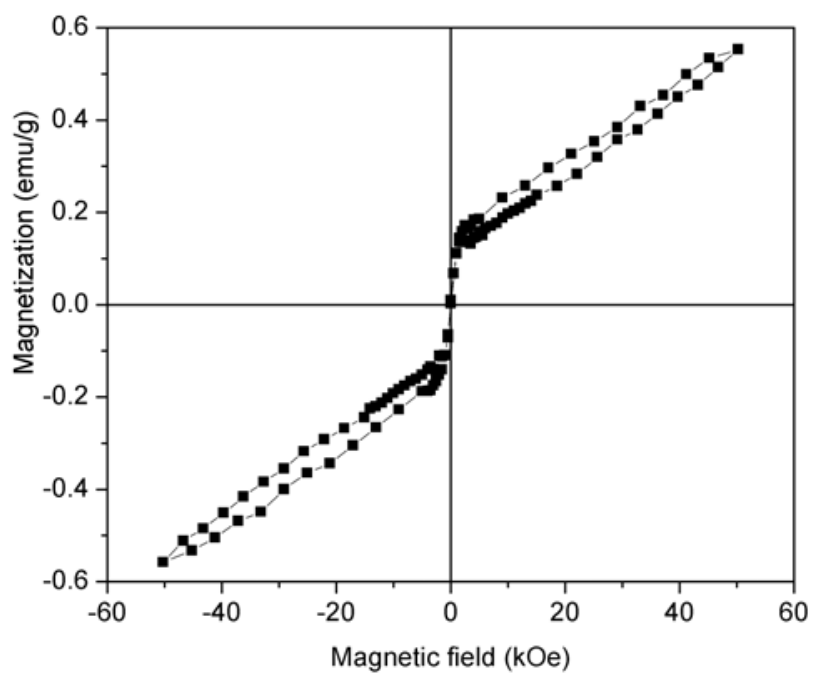

Figure $5-M(H)$ curves of the sample prepared without using $\mathrm{NaOH}$

Puc. 5 - M(H) кривые образиа, подготовленного без $\mathrm{NaOH}$ Слика $5-\mathrm{M}(\mathrm{H})$ криве узорка припремљеног без $\mathrm{NaOH}$

Recording the hysteretic curves enabled the estimation of the intrinsic coercivity field value $\left(\mathrm{H}_{\mathrm{ci}}=65 \mathrm{Oe}\right)$ and saturation magnetization $\left(\mathrm{M}_{\mathrm{s}}=0.55 \mathrm{Oe}\right)$. The obtained $\mathrm{Ms}$ value is expected for $\mathrm{NiO}$ nanoparticles (Taghizadeh, 2016). It is shown in literature that although bulk coercivity of $\mathrm{NiO}$ is around $0.8 \mathrm{Oe}, \mathrm{NiO}$ nanoparticles showed increased averaged coercivity due to size effects (around 49 Oe) (Taghizadeh, 2016). Accordingly, the coercivity observed in Figure 5 is characteristic for $\mathrm{NiO}$ nanoparticles. 
It is noteworthy that the measured hysteretic loops possess constricted middles, so-called "wasp-waisted" curves (Tauxe et al, 1996), that are often oversimplifyingly interpreted, which could result in erroneous conclusions. This shape of the curves could be a consequence of the presence of other phases in the samples. If we consider Figure 1, the presence of other phases is unlikely. Another reason of the modified shape of the hysteretic curves could be the presence of the surface moisture reflecting in the lowered saturation magnetization value and the modification of other hysteretic parameters (Durmus et al, 2011), (Lu et al, 2002). Since the investigated sample showed the $M_{s}$ and $H_{c i}$ values characteristic for NiO nanoparticles, it is clear that the observed feature could not appear for this reason. For a more precise interpretation of the magnetic properties of the investigated sample, in-depth magnetic investigation consisting of the application of different measurement protocols and a comprehensive interpretation of the obtained results should be carried out.

\section{Conclusion}

This article presents a preliminary investigation of the properties of $\mathrm{NiO}$ nanoparticles that could be used for the preparation of sensors for $\mathrm{H}_{2} \mathrm{~S}$ gas detection. Two samples are obtained by a combination of the coprecipitation method and the annealing treatment at $700{ }^{\circ} \mathrm{C}$ for 30 minutes. XRD measurements of the samples have revealed that the presence of $\mathrm{NaOH}$ in the synthesis route influences the purity of the samples. The samples obtained by using $\mathrm{NaOH}$ contained moisture $\mathrm{NaCl}$; the observed moisture could be eliminated by washing the sample with a significant amount of water. The sample prepared without $\mathrm{NaOH}$ contained pure NiO nanoparticles. FTIR and Raman spectroscopy have confirmed the presence of carbon moisture in the form of $\mathrm{C}-\mathrm{C}$ or $\mathrm{C}-\mathrm{O}$ bonds, attached to the surface of $\mathrm{NiO}$ nanoparticles. The noticed obstacle could be overcome by using commercial gelatin of some other producer, which would experience thermal degradation at lower temperatures. Hysteretic measurements have revealed the presence of wasp-wasted curves although the Ms $(0.55 \mathrm{emu} / \mathrm{g})$ and $\mathrm{Hci}(65 \mathrm{Oe})$ values are characteristic for $\mathrm{NiO}$ nanoparticles. Further investigation will be performed in the future. 
Notations and symbols

ATR - attenuated total reflection

$\mathrm{d}_{\mathrm{cr}}$ - crystallite diameter

FTIR - Fourier transform infrared spectroscopy

hkl - Miller indices of the plane

$\mathrm{H}_{\mathrm{ci}}$ - intrinsic coercivity field

$\mathrm{M}_{\mathrm{s}}$ - saturation magnetization

SQUID - superconducting quantum intereference device

XRD - X-ray diffraction

$\lambda$ - Cu Ka radiation wavelength

$\theta$ - Bragg angle

\section{References}

Alkilany, A.M., Nagaria, P.K., Hexel, C.R., Shaw, T.J., Murphy, C.J., \& Wyatt, M.D. 2009. Cellular uptake and cytotoxicity of gold nanorods: molecular origin of cytotoxicity and surface effects. Small, 5(6), pp.701-708. Available at: https://doi.org/10.1002/smll.200801546.

Bahari Molla Mahaleh, Y., Sadrnezhaad, S.K., \& Hosseini, D. 2008. NiO Nanoparticles Synthesis by Chemical Precipitation and Effect of Applied Surfactant on Distribution of Particle Size. Journal of Nanomaterials, 2(8), pp.15. Available at: https://doi.org/10.1155/2008/470595.

Balian, G., \& Bowes, J.H. 1977. The Science and Technology of Gelatin, Ward, A.G., Courts, A., Eds.; Academic Press: London, UK.

Cheng, Y.T., Rodak, D.E., Wong, C.A., \& Hayden, C.A. 2006. Effects of micro-and nano-structures on the self-cleaning behaviour of lotus leaves. Nanotechnology, 17(5), pp.1359-1362. Available at: https://doi.org/10.1088/0957-4484/17/5/032.

Chiellini, E., Cinelli, P., Grillo Fernandes, E., Kenawy E.R.S., \& Lazzeri, A. 2001. Gelatin-Based Blends and Composites. Morphological and Thermal Mechanical Characterization. Biomacromolecules, 2(1), pp.806-811. Available at: https://doi.org/10.1021/bm015519h.

Chuaynukul, K., Prodrpan, T., \& Benjakul, S. 2014. Preparation, thermal properties and characteristics of gelatin molding compound resin. Res J. Chem. Environ. Sci, 2014, 2(1), pp.1-9. ISSN 2321-1040.

Cordoba-Torresi, S.I., Hugot-Le Goff, A., \& Joiret, S. 1991. Electrochromic Behavior of Nickel Oxide Electrodes II. Identification of the Bleached State by Raman Spectroscopy and Nuclear Reactions. Journal of the Electrochemical Society, 138(6), pp.1554-1559. Available at: https://doi.org/10.1149/1.2085831.

Durmus, Z., Kavas, H., Baykal, A., Sozeri, H., Alpsoy, L., Çelik, S.Ü., \& Toprak, M.S. 2011. Synthesis and characterization of I-carnosine coated iron oxide nanoparticles. Journal of Alloys and Compounds, 509(5), pp.2555-2561. Available at: https://doi.org/10.1016/j.jallcom.2010.11.088. 
Faust, C.B. 1997. Modern chemical techniques: An Essential Reference for Students and Teachers. Royal Society Of Chemistry, London, UK.

Fleck, M., \& Bohaty, L. 2004. Three novel non-centrosymmetric compounds of glycine: glycine lithium sulfate, glycine nickel dichloride dihydrate and glycine zinc sulfate trihydrate, Acta Crystallographica Section C, 60(5), pp.291-295. Available at: https://doi.org/10.1107/S0108270104009825.

Harrington, W.F., \& von Hippel, P.H., 1962. The structure of collagen and gelatin. Advances in Protein Chemistry, 16(1), pp.1-138. Available at: https://doi.org/10.1016/S0065-3233(08)60028-5.

Jagadeesh, D., Prashantha, K., Mithil Kumar Nayunigari N., \& Maity, A. 2016. Effect of Gelatin Content on Potato Starch Green Composite Films. Indian Journal of Advances in Chemical Science, 4(4), pp.355-361.

Jana, N.R., Chen, Y. \& Peng, X. 2004. Size-and Shape-Controlled Magnetic ( $\mathrm{Cr}, \mathrm{Mn}, \mathrm{Fe}, \mathrm{Co}, \mathrm{Ni})$ Oxide Nanocrystals via a Simple and General Approach. Chemistry of materials, 16(20), pp.3931-3935. Available at: https://doi.org./10.1021/cm049221k.

Jeffrey, F.J. 2015. Manuals Combined: Navy Air Force And Army Occupational Health And Safety - Including Fall Protection And Scaffold Requirements. Department of the Navy Fall Protection Guide. Available at: http://www.public.navy.mil/navsafecen/Documents/OSH/FP/FALL_PROTECTIO N_GUIDE_MAY_15.pdf. Accessed: 05.05.2018.

Kamal, H., Elmaghraby, E.K., Ali, S.A., \& Abdel-Hady, K. 2005. The electrochromic behavior of nickel oxide films sprayed at different preparative conditions. Thin solid films, 483(2), pp.330-339. Available at: https://doi.org/10.1016/j.tsf.2004.12.022.

Kapse, V.D., Ghosh, S.A., Chaudhari, G.N., \& Raghuwanshi, F.C. 2008. Nanocrystalline $\ln _{2} \mathrm{O}_{3}$-based $\mathrm{H}_{2} \mathrm{~S}$ sensors operable at low temperatures. Talanta, 76(3), pp.610-616. Available at: https://doi.org/10.1016/j.talanta.2008.03.050.

Kossyrev, P.A., Yin, A., Cloutier, S.G., Cardimona, D.A., Huang, D., Alsing, P.M., \& Xu, J. M. 2005. Electric field tuning of plasmonic response of nanodot array in liquid crystal matrix. Nano Letters, 5(10), pp.1978-1981. Available at: https://doi.org/10.1021/nl0513535.

Lee, G., Cheng, Y., Varanasi, C.V., \& Liu, J. 2014. Influence of the nickel oxide nanostructure morphology on the effectiveness of reduced graphene oxide coating in supercapacitor electrodes. The Journal of Physical Chemistry C, 118(5), pp.2281-2286. Available at: https://doi.org/10.1021/jp4094904.

Lin, H.M., Hsu, C.M., Yang, H.Y., Lee, P.Y., \& Yang, C.C. 1994. Nanocrystalline $\quad \mathrm{WO}_{3}$-based $\mathrm{H}_{2} \mathrm{~S}$ sensors. Sensors and Actuators $B$ : Chemical, 22(1), pp.63-68. Available at: https://doi.org/10.1016/09254005(94)01256-3.

Ling, W.C. 1978. Thermal degradation of gelatin as applied to processing of gel mass, Journal of pharmaceutical sciences, 67(2), pp.218-223. Available at: https://doi.org/10.1002/jps.2600670223. 
Lu,Y., Yin,Y., Mayers, B.T., \& Xia, Y. 2002. Modifying the surface properties of superparamagnetic iron oxide nanoparticles through a sol-gel approach. Nano letters, 2(3), pp.183-186. Available at: https://doi.org/10.1021/nl015681q.

Maia, A.O.G., Meneses, C.T., Menezes, A.S., Flores, W.H., Melo, D.M.A., \& Sasaki, J.M. 2006. Synthesis and X-ray structural characterization of $\mathrm{NiO}$ nanoparticles obtained through gelatin. Journal of non-crystalline solids, 352(3235), pp.3729-3733. Available at: https://doi.org/10.1016/j.jnoncrysol.2006.03.103.

MalekAlaie, M., Jahangiri, M., Rashidi, A.M., HaghighiAsl, A., \& Izadi, N. 2015. Selective hydrogen sulfide $\left(\mathrm{H}_{2} \mathrm{~S}\right)$ sensors based on molybdenum trioxide $\left(\mathrm{MoO}_{3}\right)$ nanoparticle decorated reduced graphene oxide. Materials Science in Semiconductor Processing, 38(5), pp.93-100. Available at: https://doi.org/10.1016/j.mssp.2015.03.034.

Milić, M.M., Nikolić, V.N. \& Jovanović, S. 2017. Synthesis and characterization of nanocrystalline $\mathrm{Fe}_{\mathrm{x}} \mathrm{O}_{\mathrm{y}} / \mathrm{Gd}_{2} \mathrm{O}_{3} / \mathrm{SiO}_{2}$ composite powder. Ceramics International, 43(16), pp.14044-14049. Available at: https://doi.org/10.1016/j.ceramint.2017.07.138.

Müller, J., Lupton, J. M., Rogach, A.L., Feldmann, J., Talapin, D.V., \& Weller, H. 2005. Monitoring surface charge migration in the spectral dynamics of single $\mathrm{Cd} \mathrm{Se} / \mathrm{Cd} \mathrm{S}$ nanodot/nanorod heterostructures. Physical Review B, 72(20), p.205339. Available at: https://doi.org/10.1103/physrevb.72.205339.

Navarrete, E., Bittencourt, C., Umek, P., \& Llobet, E. 2018. AACVD and gas sensing properties of nickel oxide nanoparticle decorated tungsten oxide nanowires. Journal of Materials Chemistry C, 6(19), pp.5181-5192. Available at: https://doi.org/10.1039/c8tc00571k.

Nikolić, V.N., Milić, M., Jovanović, S. \& Girman, V. 2017. $\mathrm{Fe}_{3} \mathrm{O}_{4}$ Nanoparticles as Additives for GAMMA-Ray Shielding: Structural and Surface Characterization. Scientific Technical Review, 67(2), pp.20-26. ISSN: 18200206.

Nikolić, V.N., Tadić, M., \& Spasojević, V. 2016. Thermal stability and magnetic properties of $\varepsilon-\mathrm{Fe}_{2} \mathrm{O}_{3}$ polymorph. In: VII International Scientific Conference on Defensive Technologies, OTEH, Belgrade, pp.1-21. October 6-7. Available at: https://www.researchgate.net/profile/Srdjan_Zivkovic3/publication/321973454_SUR FACE_TEXTURE_FILTRATION_INTERNATTIONAL_STANDARDS_and_FILTRA TIONS_TECHNIQUE_OVERVIEW/links/5a3baf67a6fdccb29dc873ba/SURFACETEXTURE-FILTRATIONN-INTERNATIONAL-STANDARDS-and-FILTRATIONSTECHNIQUE-OVERVIEW.pdf.

Privalov, P.L., Tiktopulo, E.I., \& Tischenko, V.M.1979. Stability and mobility of the collagen structure. Journal of Molecular Biology, 127(2), pp.203-216. Available at: https://doi.org/10.1016/0022-2836(79)90240-7.

Rahdar, A., Aliahmad, M., \& Azizi, Y. 2015. NiO nanoparticles: synthesis and characterization. Journal of Nanostructures, 5(2), pp.145-151. ISSN: 2251$788 \mathrm{X}$. 
Rout, C.S., Hedge, M., \& Rao, C.N.R. 2008. $\mathrm{H}_{2} \mathrm{~S}$ sensors based on tungsten oxide nanostructures. Sensors and Actuators B: Chemical, 128(2), pp.488-493. Available at: https://doi.org/10.1016/j.snb.2007.07.013.

Salimi, A., Sharifi, E., Noorbakhsh, A., \& Soltanian, S. 2017. Immobilization of glucose oxidase on electrodeposited nickel oxide nanoparticles: direct electron transfer and electrocatalytic activity. Biosensors and Bioelectronics, 22(12), pp.3146-3153. Available at: https://doi.org/10.1016/j.bios.2007.02.002.

Samouillan, V., Delaunay, F., Dandurand, J., Merbahi, N., Gardou J., Yousfi, M., Gandaglia A., Spina M., \& Lacabanne, C., 2011. The Use of Thermal Techniques for the Characterization and Selection of Natural Biomaterials. Journal of Functional Biomaterials, 2(1), pp.230-248. Available at: https://doi.org/10.3390/jfb2030230.

See, R.F., Kruse, R.A., \& Strub, W.M. 1998. Metal-Ligand Bond Distances in First-Row Transition Metal Coordination Compounds: Coordination Number, Oxidation State, and Specific Ligand Effects. Inorganic Chemistry, 37(1), pp.5369-5375. Available at: https://doi.org/10.1021/ic971462p.

Sellmyer, D.J., Zheng, M., \& Skomski, R. 2001. Magnetism of Fe, Co and $\mathrm{Ni}$ nanowires in self-assembled arrays. Journal of Physics: Condensed Matter, 13(25), pp.433-447. Available at: https://doi.org/10.1088/09538984/13/25/201.

Taghizadeh, F. 2016. The Study of Structural and Magnetic Properties of $\mathrm{NiO}$ Nanoparticles. Optics and Photonics Journal, 6(08), pp.164-169. Available at: https://doi.org/10.4236/opj.2016.68B027.

Tauxe, L., Mullender, T.A.T., \& Pick, T. 1996. Potbellies, wasp-waists, and superparamagnetism in magnetic hysteresis, Journal of Geophysical Research: Solid Earth, 101(B1), pp.571-583. Available at: https://doi.org/10.1029/95jb03041.

Tramsdorf, U. I., Bigall, N. C., Kaul, M. G., Bruns, O. T., Nikolic, M. S., Mollwitz, B., \& Förster, S. 2007. Size and surface effects on the MRI relaxivity of manganese ferrite nanoparticle contrast agents. Nano letters, 7(8), pp.24222427. Available at: https://doi.org/10.1021/nl071099b.

Wang, Y., Cao, J., Kong, F., Xia, H., Zhang, J., \& Wu, S. 2008. Lowtemperature $\mathrm{H}_{2} \mathrm{~S}$ sensors based on $\mathrm{Ag}$-doped $\alpha-\mathrm{Fe}_{2} \mathrm{O}_{3}$ nanoparticles. Sensors and Actuators B: Chemical, 131(1), pp.183-189. Available at: https://doi.org/10.1016/j.snb.2007.11.002.

Xing, W., Li, F., Yan, Z., \& Lu, G.Q. 2004. Synthesis and electrochemical properties of mesoporous nickel oxide. Journal of Power Sources, 134(2), pp.324-330. Available at: https://doi.org/10.1016/j.jpowsour.2004.03.038.

You, T., Niwa, O., CHEN, Z., Hayashi, K., Tomita, M., \& Hirono,S. 2003. An amperometric detector formed of highly dispersed Ni nanoparticles embedded in a graphite-like carbon film electrode for sugar determination. Analytical chemistry, 75(19), pp.5191-5196. https//doi.org/10.1021/ac034204k. 
ХАРАКТЕРИСТИКИ НАНОЧАСТИЦ $\mathrm{NIO}$, ПОДГОТОВЛЕННЫХ С ПОМОЩЬЮ ЖЕЛАТИНА ПРИ ПРОСТОМ И НЕДОРОГОМ МЕТОДЕ ОБОБЩЕНИЯ

Виолетта Н. Николич ${ }^{a}$, Мартина Д. Гилич ${ }^{6}$, Воислав В. Спасоевич $^{a}$

а Белградский университет, Институт ядерных наук „Винча“,

Лаборатория теоретической физики и физики конденсированного

Состояния, г. Белград, Республика Сербия

б Белградский университет, Институт физики,

Лаборатория для исследований в области электронных материалов,

г. Белград, Республика Сербия

ОБЛАСТЬ: химические технологии

ВИД СТАТЬИ: оригинальная научная статья

ЯЗЫК СТАТЬИ: английский

Резюме:

Нанокомпозитные материалы, содержащие наночастицы NiO, нанесенные на нанопровода $\mathrm{WO}_{3}$ можно использовать для мониторинга уровня $\mathrm{H}_{2} \mathrm{~S}$-газа. Эфффективность данного материала в основном определяется свойствами этапа NiO. Проведенное исследование представляет собой первый этап в подготовке модифицированного материала $\mathrm{NiO} / \mathrm{WO}_{3}$. B данной статье представлено получение наночастиц NiO простым u недорогим методом обобщения. Поведение наноразмерных частиц NiO исследуется с помощью рентаеновской дифракции, инфрракрасной спектроскопии с Фурье-преобразованием, рамановской спектроскопии и гистерезисных измерений.

Ключевые слова: NiO, дифракционные измерения, спектроскопия, наночастицы, материалы.

КАРАКТЕРИЗАЦИЈА NIО НАНОЧЕСТИЦА ПРИПРЕМЉЕНИХ ПОМОЋУ ЖЕЛАТИНА ТОКОМ ПОСТУПКА „LOW-COST” СИНТЕЗЕ

Виолета, Н. Николић ${ }^{a}$, Мартина Д. Гилић ${ }^{6}$, Војислав В. Спасојевић $^{a}$

"Универзитет у Београду, Инститит за нуклеарне науке „Винча”,

Лабораторија за теоријску физику и фризику кондензоване материје,

Београд, Република Србија

${ }^{\sigma}$ Универзитет у Београду, Институт за фризику,

Лабораторија за истраживања у области електронских материјала,

Београд, Република Србија

ОБЛАСТ: хемијске технологије

ВРСТА ЧЛАНКА: оригинални научни чланак

ЈЕЗИК ЧЛАНКА: енглескИ 


\section{Сажетак:}

Нанокомпозитни материјал који садржи наночестице NiO нанете на $\mathrm{WO}_{3}$ наножице може се користити за мониторине нивоа $\mathrm{H}_{2} \mathrm{~S}$ гаса. Ефрикасност овог материјала највећим је делом одређена својствима NiO фразе. Изведена студија представља прву фразу у припреми модифрикованог материјала $\mathrm{NiO}_{\mathrm{WO}}$. У овом раду NiO наночестице су припремљене једноставним „/ow-cost” методом синтезе. Понашање наноструктурних NiO честица испитивано је рентаенском дифракцијом, инфрацрвеном спектроскопијом са Фуријеовом трансорормацијом, раманском спектроскопијом и хистерезним мерењем.

Кључне речи: NiO, дифрракциона мерења, спектроскопија, наночестице, материјали.

Paper received on / Дата получения работы / Датум пријема чланка: 08.08.2018.

Manuscript corrections submitted on / Дата получения исправленной версии работы / Датум достављања исправки рукописа: 03.09.2018.

Paper accepted for publishing on / Дата окончательного согласования работы / Датум коначног прихватања чланка за објављивање: 05.09.2018.

(C) 2019 The Authors. Published by Vojnotehnički glasnik / Military Technical Courier

(www.vtg.mod.gov.rs, втг.мо.упр.срб). This article is an open access article distributed under the terms and conditions of the Creative Commons Attribution license (http://creativecommons.org/licenses/by/3.0/rs/).

(c) 2019 Авторы. Опубликовано в «Военно-технический вестник / Vojnotehnički glasnik / Military Technical Courier» (www.vtg.mod.gov.rs, втг.мо.упр.срб). Данная статья в открытом доступе и распространяется в соответствии с лицензией «Creative Commons» (http://creativecommons.org/licenses/by/3.0/rs/).

(c) 2019 Аутори. Објавио Војнотехнички гласник / Vojnotehnički glasnik / Military Technical Courier (www.vtg.mod.gov.rs, втг.мо.упр.срб). Ово је чланак отвореног приступа и дистрибуира се у складу са Creative Commons licencom (http://creativecommons.org/licenses/by/3.0/rs/). 